\title{
Gonad fatty acids and trophic interactions of the echinoid Psammechinus miliaris
}

\author{
Adam D. Hughes ${ }^{1, *}$, Ana I. Catarino ${ }^{1,2}$, Maeve S. Kelly ${ }^{1}$, David K. A. Barnes ${ }^{3}$, \\ Kenneth D. Black ${ }^{1}$ \\ ${ }^{1}$ Scottish Association for Marine Science, Dunbeg, Oban, Argyll PA37 1QA, UK \\ ${ }^{2}$ Faculdade de Ciências da Universidade de Lisboa, Campo Grande, 1149-016 Lisboa, Portugal \\ ${ }^{3}$ Biological Sciences Division, British Antarctic Survey, Natural Environment Research Council, High Cross, \\ Madingley Road, Cambridge CB3 OET, UK
}

\begin{abstract}
Variation in gonadal somatic indices (GSI) and fatty acid signatures of 2 contrasting Scottish west coast populations of the echinoid Psammechinus miliaris were examined. P. miliaris was sampled from both the shallow subtidal and at the upper limit of its distribution in the intertidal. The intertidal population had a significantly higher GSI than the subtidal at both locations. Multivariate analysis (ANOSIM) of the fatty acid signature showed significant variation between the 2 depths as well as between sex and location. SIMPER analysis indicated a complex pattern of variation between location and depths. Both 20:4(n-6) and 20:5(n-6), associated with brown algae, were found in higher levels in subtidal populations, while levels of 22:6(n-3) were higher in the intertidal at one site, and 18:4(n-3) higher at the other. Of these acids, 22:6(n-3) is associated with filter feeding invertebrates, and 18:4(n-3) with green algae. Omnivorous diets in urchins have been associated with increased gonadal growth and the results from this study strongly suggest that the observed differences in GSI between intertidal and subtidal $P$. miliaris result from a higher quality diet in the intertidal, consisting of invertebrates and green algae.
\end{abstract}

KEY WORDS: Sea urchin · Fatty acid - Gonadal somatic indices $\cdot$ Psammechinus miliaris $\cdot$ Diet

\section{INTRODUCTION}

Although the omnivorous grazing habits of several urchin species are well documented (Forster 1959, Himmelman \& Steele 1971, Lawerence 1975, Briscoe \& Sebens 1988) the literature focuses on their herbivorous habits. A mixed diet (i.e. including fauna) increases gonad growth rates of echinoids both in the laboratory (Cook et al. 1998, Fernandez \& Boudouresque 2000, Pearce et al. 2004) and in the field (Cook et al. 2000).

Psammechinus miliaris is a relatively small echinoid, reaching a maximum test diameter of $50 \mathrm{~mm}$. Its depth distribution has an upper limit in the low littoral and it is found down to approximately $100 \mathrm{~m}$, with a range extending from Scandinavia to Morocco, although it is absent from the Mediterranean. P. miliaris is an oppor- tunistic omnivore, feeding on a wide range of material including macroalgae and encrusting invertebrates as well as scavenging on larger dead animals (Kelly \& Cook 2001). In the study region on the west coast of Scotland, $P$. miliaris typically occurs in the littoral and sub-littoral of sheltered sea lochs at densities of up to 350 ind. $\mathrm{m}^{-2}$ (Kelly 2000). Studies of echinoid gonadal somatic indices (GSI, the index of gonad mass relative to whole organism size) have revealed considerable variability at both spatial and temporal scales. Kelly (2000) found that GSIs were higher in the intertidal than in subtidal populations of $P$. miliaris in a Scottish sea loch. It was proposed that this difference was a result of better food quality and/or quantity found in the intertidal, and more specifically the greater abundance of invertebrate prey in the intertidal. 
There are strong links between diet quality and somatic and reproductive growth for echinoid species (Floreto et al. 1996). Psammechinus miliaris individuals that have been fed salmon feed (Otero-Villanueva et al. 2004), or that have grazed on the encrusting biota of scallop lines, have significantly higher GSIs than those fed algae (Cook et al. 2000). This study examines the diet of natural populations of $P$. miliaris and relates this to variations in their GSIs. Stomach content analysis can be problematic (Howell et al. 2003) especially for a species with a small jaw size, so an alternative method of dietary biomarkers was used.

Ecological studies have used a range of biomarkers, including analysis of stable isotope ratios (Fry \& Sherr 1984), analysis of algal pigments from stomach contents (Boyd et al. 1980, Kleppel \& Pieper 1984), and fatty acid analysis of tissue or whole organisms (Sargent \& Falkpetersen 1981). The current study used the fatty acid composition of the gonad to explore trophic interactions of Psammechinus miliaris. These biomarkers (herein known as the fatty acid signature) have been used to explore the feeding ecology of a number of marine organisms (Pond et al. 1997, Grahl-Nielsen et al. 2003, Laureillard et al. 2004). This technique assumes that dietary lipids are broken down into their constituent fatty acids. These fatty acids are at least partly conservative and can be anabolized into the consumer's tissues. Certain components of the signature, or ratios of these components, can act as dietary

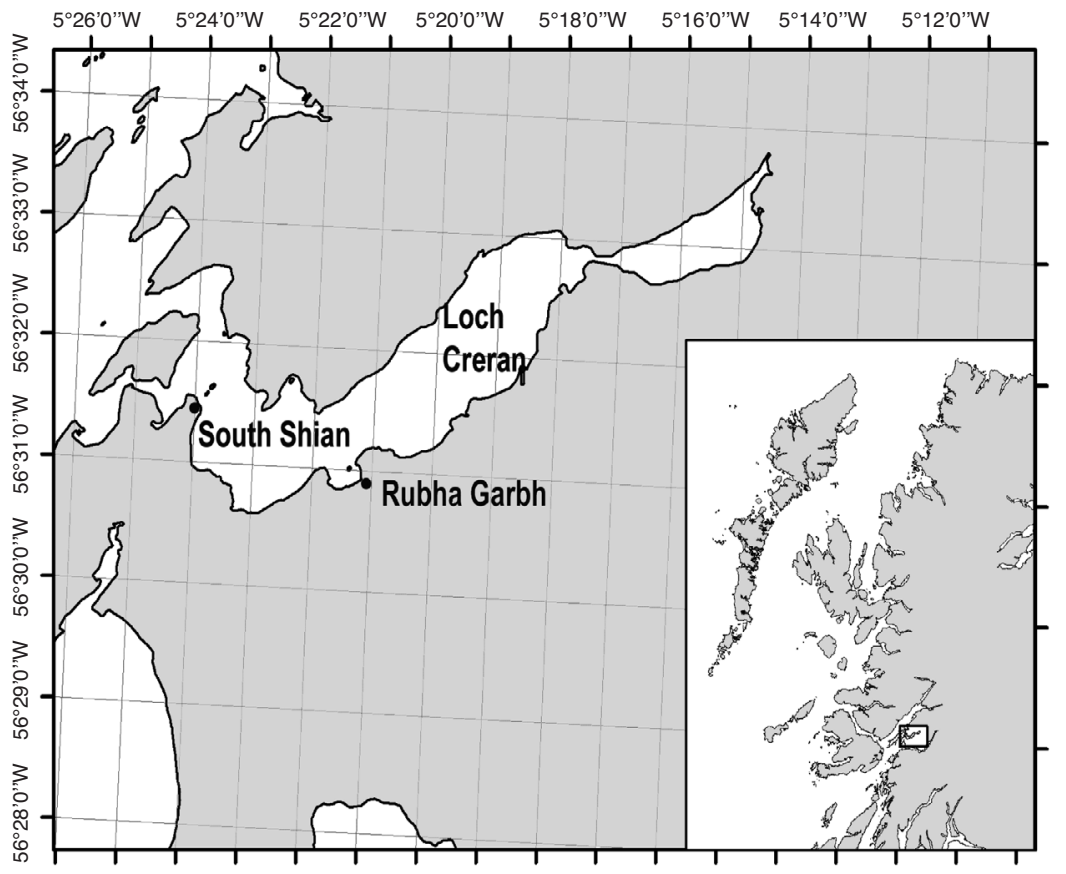

Fig. 1. Positions of the study sites at Loch Creran on the west coast of Scotland, NW Europe indicators. However, the interpretation in higher trophic levels can be confounded by de novo biosynthesis, metabolism and catabolism of fatty acids (Dalsgaard et al. 2003).

The present study addressed 2 main hypotheses: (1) for the study populations, the GSI of Psammechinus miliaris found in the intertidal are higher than those in the subtidal, and these differences are a result of depth and are not confounded by simple spatial variation; (2) intertidal and subtidal populations can be differentiated in terms of their fatty acid signatures, reflecting a difference in diets between the 2 habitats. This study also explored the nutritional and ecological implications of these inter-habitat differences.

\section{MATERIALS AND METHODS}

Study site. The study was conducted at 2 locations on the south shore of Loch Creran, west coast of Scotland (Fig. 1). Loch Creran is a silled sea loch $12.8 \mathrm{~km}$ long, with 4 basins reaching a maximum depth of $49 \mathrm{~m}$. It has been characterized as a well-mixed system with a flushing time of $3 \mathrm{~d}$ (Black et al. 2000). The study locations Rubha Garbh (RG) and South Shian (SS), separated by $5 \mathrm{~km}$, were similar in terms of rugosity and profile and were characterized by boulders, cobbles and pebbles on a mixed sand and mud substrate. The intertidal was dominated by fucoid algae and by Laminaria saccharina in the shallow subtidal.

Field protocol. Five Psammechinus miliaris of approximately equal test diameter were collected from each of 2 replicate sites, each of 2 depths (intertidal and subtidal), and each of 2 locations (Fig. 2). Collections from each location were within $5 \mathrm{~d}$ of each other. Those from the intertidal zone were collected from an area just above Extreme Low Water Springs (ELWS), which is exposed for approximately $2.5 \mathrm{~h}$ for 3 to 5 consecutive days on spring tides. Those from the subtidal zone were collected using snorkel at a depth of 2 to $3 \mathrm{~m}$. The specimens from each replicate were collected within a $1 \mathrm{~m}$ radius. The replicate sites at each location were approximately $10 \mathrm{~m}$ apart. The collected individuals were transferred to the laboratory and maintained in running seawater without food until analysis (within $48 \mathrm{~h}$ ).

Laboratory analysis. Test diameter $(\mathrm{mm})$ and wet mass $(\mathrm{g})$ for each indi- 


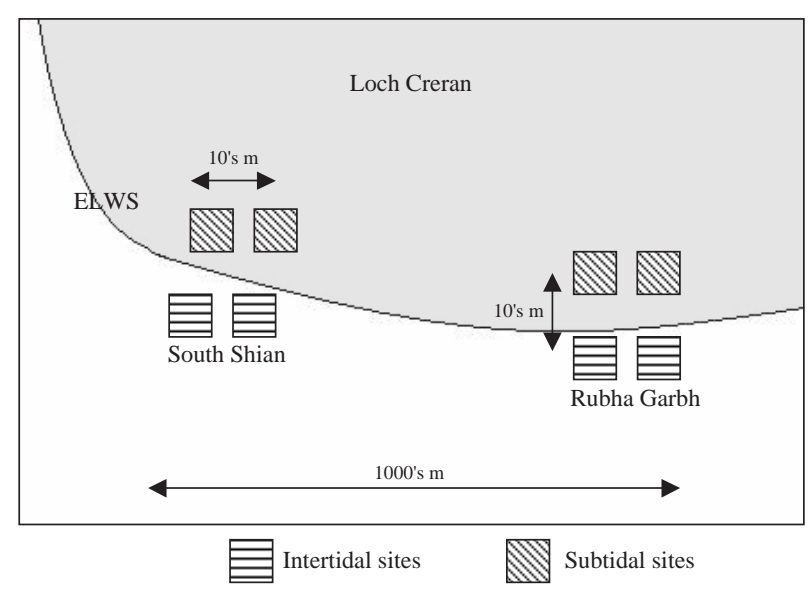

Fig. 2. Diagrammatic representation of the experimental layout. ELWS: Extreme Low Water Springs

vidual Psammechinus miliaris were determined prior to the removal of the gonad. Test diameter was measured 3 times using adapted Vernier calipers to obtain a mean diameter. The excised gonad was weighed, and a small sample taken for microscopic determination of sex and maturity stage. The maturity stage was determined using a wet squash and scored on a 6-point scale (stage I: recovery; stage II: early growth; stage III: premature; stage IV: mature; stage V: partially spawned; and stage VI: spent; Kelly 2001). The GSIs were calculated for each individual using the formula:

GSI = wet mass gonad/(wet mass of whole test $\times 100)$

The dissected gonad was placed in chloroform: methanol $\left(2: 1,2 \mathrm{~cm}^{3}\right)$, and stored under nitrogen until ready for lipid extraction $(>1 \mathrm{~h})$.

Lipid extraction and fatty acid analysis. The gonad was homogenized in chloroform:methanol $\left(2: 1,10 \mathrm{~cm}^{3}\right)$, and stored under nitrogen overnight at $4^{\circ} \mathrm{C}$. Prior to storage, the fatty acid standard 23:0 (400 $\left.\mu \mathrm{l}, 0.5 \mathrm{mg} \mathrm{g}^{-1}\right)$ was added to each sample as an internal standard. The lipid was then extracted and transesterified to fatty acid methyl esters (FAMEs). The FAMEs were purified using thin-layer chromatography and then stored in hexane under nitrogen at $-16^{\circ} \mathrm{C}$ for no longer than $1 \mathrm{wk}$ prior to gas chromatography.

The purified FAMEs were separated by a Perkin Elmer 8320 gas chromatograph equipped with split injector (100:1), flame ionization detector (FID) and a Zebron ZB-WAX fused silica capillary column (30 $\mathrm{m} \times$ $0.25 \mathrm{~mm}$ inner diameter, $0.25 \mu \mathrm{m}$ film thickness). Helium was the carrier gas and the oven temperature was programmed to increase from 160 to $240^{\circ} \mathrm{C}$ at $4^{\circ} \mathrm{C}$ $\mathrm{min}^{-1}$, then held for $10 \mathrm{~min}$. In order to store and integrate the chromatograms, the detector output was coupled to a data system (Varian Star ${ }^{\mathrm{TM}}$ ). The FAMEs were identified by comparing their retention times with those of authentic standards, with the exception of 16:0 dimethylacetal and 20:2 non-methylene interrupted dienes which were identified using retention times from a previous study (Cook et al. 2000). All samples were run on the same column and under the same conditions. Individual fatty acids were identified and the relative content of each one was determined using peak areas and expressed as the percentage by weight of the total fatty acids characterized. This was then converted to relative mass per gram of wet weight of gonad tissue $\left(\mathrm{mg} \mathrm{g}^{-1}\right)$, using the response of the internal standard.

Statistical analysis. Prior to investigation of GSI variability, the relationships between test diameter and whole wet mass, gonad wet mass and GSI were examined using Pearson's product-moment correlation. Prior to all parametric univariate analysis, data normality was tested using the Kolmogorov-Smirnov test; any data found to be significantly different was log transformed to meet assumptions of normality. Data were also checked for homogeneity of variance using Cochran's $C$-test.

Differences in test diameter and GSI were tested using a 3-factor ANOVA with depth (2 levels and fixed) being orthogonal to location (2 levels and random), and sites nested within location (2 levels). Oneway ANOVA was used to examine differences between test diameter and gonadal indices grouped by sex, and to examine sex differences between specific fatty acids. Nested ANOVAs were used to assess differences in specific fatty acids between depths at each site. The data were post hoc pooled if $F$ for the nested factor was sufficiently large $(p<0.25)$, in order to reduce chances of type II error (Underwood 1997). Differences between the proportion of each sex and maturity stage occurring at different locations, depths and sex were tested using chi-squared test.

All multivariate analysis was carried out using the PRIMER v5 (Plymouth Routines In Multivariate Ecological Research). The data were left untransformed (Howell et al. 2003) and converted into similarity matrices using Euclidean distances as the metric. To visualize data similarity patterns, we used non-metric multidimensional scaling (nMDS). These plots produce a 2-dimensional arrangement of data such that those individuals with similar fatty acid signatures are placed closer together than those that are more dissimilar. We then used permutation-based analysis of similarity (ANOSIM) routines as the hypothesis testing framework. Crossed ANOSIM was used (Warwick et al. 1990) to examine differences in fatty acid signatures across 2 factors. Differences in the fatty acid signatures with depth were explored using the similarity percentages routine (SIMPER). 

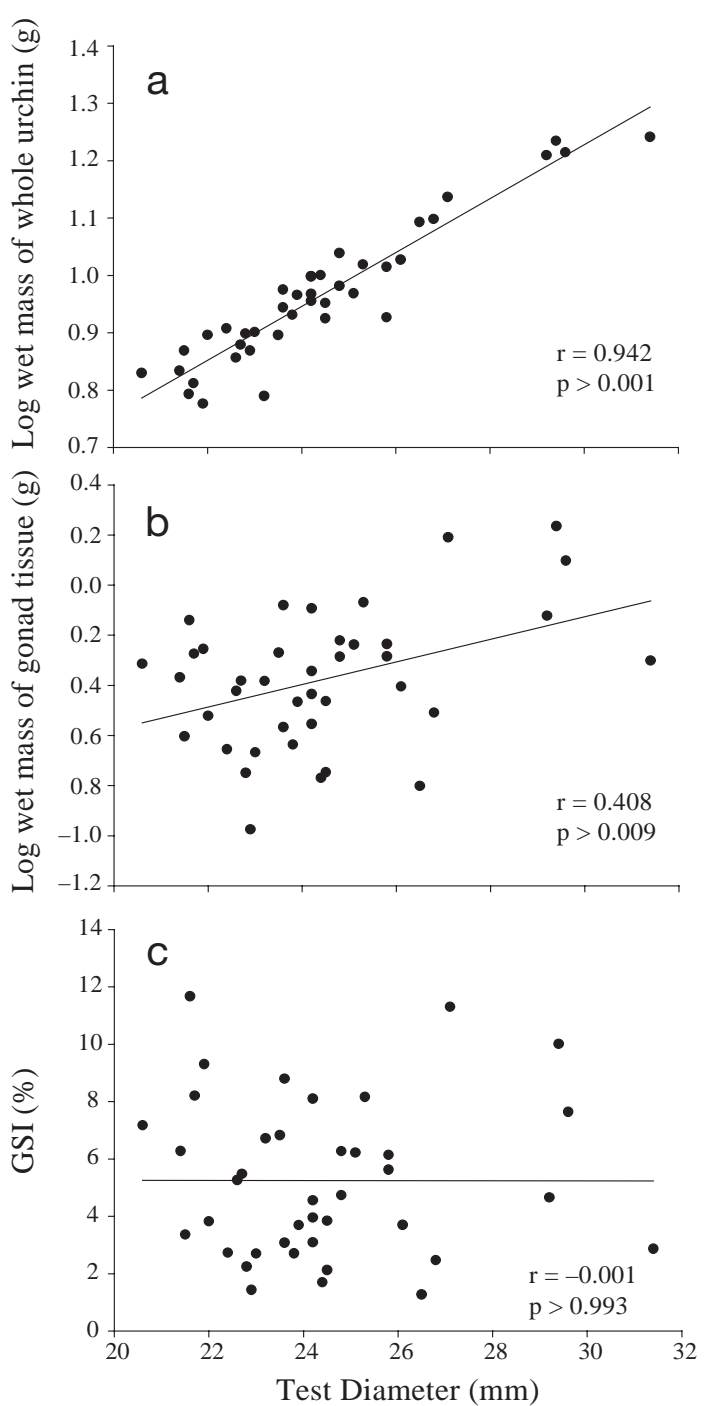

Fig. 3. Psammechinus miliaris. Test diameter versus (a) wet mass of whole urchin, (b) wet mass of gonad tissue, and (c) gonadal somatic index (GSI)

\section{RESULTS}

Pearson correlation values (r statistic) and associated probabilities demonstrated a significant relationship between test diameter and (1) whole wet mass and (2) gonad wet mass as expected (Fig. 3a \& b, respectively). There was no significant correlation between test diameter and GSI (Fig. 3c) thus establishing GSI as a size-independent metric.

\section{Gonad index variation with location, depth and sex}

The mean test diameter (approximately $25 \mathrm{~mm}$ ) differed little between replicates, locations and depths (Fig. 4a). There was, however, a distinct trend in GSI with both location and depth. The GSIs of Psammechinus miliaris at RG were approximately two-thirds lower than those at SS at both depths (Fig. 4b). Furthermore, at both RG and SS, the GSIs of intertidal urchins were nearly double those of the subtidal population. So the individuals with the largest GSI (approximately $8 \%$ ) were those in the intertidal at SS, and those with the smallest (approximately $3 \%$ ) were those in the subtidal at RG.

Following a multifactorial ANOVA of these data, no significant difference in test diameter of Psammechinus miliaris was found between locations ( $\mathrm{df}=1, F=$ $0.09, \mathrm{p}=0.82$ ) or depths ( $\mathrm{df}=1, F=1.05, \mathrm{p}=0.45)$. In contrast, there were significant differences between the GSIs of intertidal and subtidal specimens but there were no significant interactions with, or effect from, location (Table 1). There was no significant difference between the test diameter ( $\mathrm{df}=1, F=0.02, \mathrm{p}=0.898$ ) or GSI ( $\mathrm{df}=1, F=0.10, \mathrm{p}=0.758$ ) between the sexes.

The distribution of sex and maturity stage with respect to depth and location showed no significant bias, with males and females being equally common at both locations and depths (Table 2). In contrast to
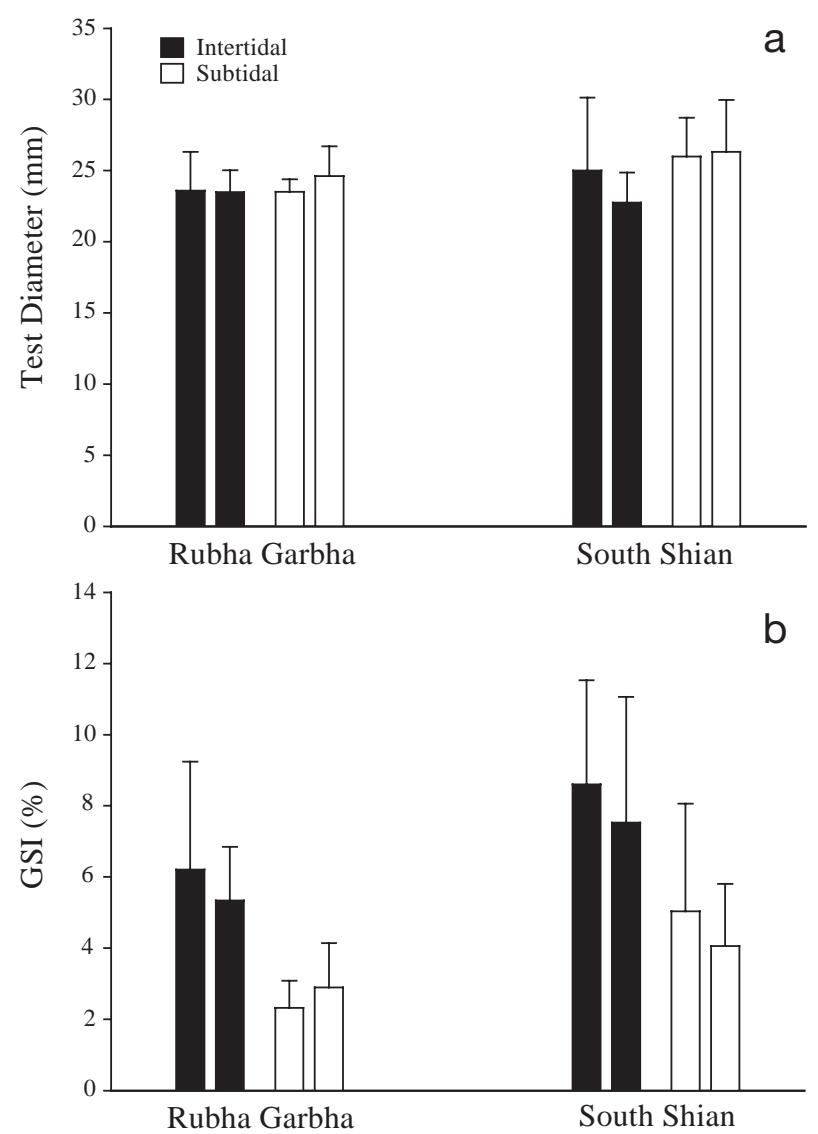

Fig. 4. Psammechinus miliaris. Mean $( \pm 95 \% \mathrm{CI})$ at location, depth and site: (a) test diameter, (b) GSI 
Table 1. Psammechinus miliaris. Multifactorial ANOVA of gonadal somatic indices with depth (2 levels and fixed) being orthogonal to location (2 levels and random), and sites nested within location (2 levels) $(n=5)$

\begin{tabular}{|lrrrrr|}
\hline Source of variation & df & \multicolumn{1}{c}{ SS } & MS & \multicolumn{1}{c|}{$F$} & $\mathrm{p}$ \\
\hline Depth & 1 & 111.63 & 111.63 & 352.30 & 0.03 \\
Location & 1 & 44.75 & 44.75 & 26.76 & 0.22 \\
Depth $\times$ Location & 1 & 0.32 & 0.32 & 0.24 & 0.67 \\
Sample (Location) & 2 & 5.36 & 2.68 & 2.03 & 0.33 \\
Habitat $\times$ Sample (Location) & 2 & 2.64 & 1.32 & 0.33 & 0.72 \\
Error & 32 & 127.24 & 3.98 & & \\
Total & 39 & 291.93 & & & \\
\hline
\end{tabular}

lack of sex differentiation in GSI, there was a significant difference in the proportion of individuals at stage IV rather than stage III (males were developmentally more advanced).

\section{Fatty acid analysis}

The data were divided by depth and location, with replicate sites within a location grouped together. The predominant fatty acid across all depths and location was eicosapentaenoic acid (EPA) 20:5(n-3), ranging from $15.1 \%$ in the intertidal at SS to $18.4 \%$ in the subtidal at SS (Table 3, Fig. 5). The second most common was arachidonic acid (AA) 20:4(n-6), ranging from 11.07 to $14.20 \%$. Polyunsaturated fatty acids (PUFAs) were the largest class, followed by saturated fatty acids (SFAs) and monounsaturated fatty acids (MUFAs). This pattern was consistent over both depths and locations. Total FAMEs $\left(\mathrm{mg} \mathrm{g}^{-1}\right)$ were higher in the intertidal compared to the subtidal for each site, although the levels of FAMEs at SS were higher than at RG.

\section{Multivariate analysis of fatty acid signature}

Multivariate analysis (ANOSIM) of sites showed no significant difference in the fatty acid signature between the replicate sites at each location (Table 4) and so the data were pooled prior to further analysis.

\section{Depth and location}

The nMDS plots (Fig. 6) revealed significant separation in the fatty acid signatures by depth at each location. This separation was supported by results from a crossed ANOSIM $(\mathrm{R}=0.308, \mathrm{p}<0.001)$ that showed there was a significant difference between the depths when averaged across location. There was also a sig- nificant difference between the 2 locations, when averaged over depth $(\mathrm{R}=$ $0.268, p=0.01$ ). The pattern of separation by location was clearer in the intertidal compared to the subtidal (Fig. 7). SIMPER was used to explore the difference by determining which fatty acids contributed most to the differences in the multivariate signature (Table 5); this difference varied between the locations. At SS, 22:6(n-3) contributed most to the differences between depth, and was significantly higher in the intertidal while 18:4(n-3) was significantly lower in the intertidal. At RG this fatty acid was significantly higher in the intertidal.

\section{Sex}

The nMDS plot clearly demonstrated that fatty acid composition varied between the sexes (Fig. 8). This was supported by a 1-way ANOSIM that showed there was a significant difference in the fatty acid signature $(\mathrm{R}=0.484, \mathrm{p}<0.001)$. SIMPER revealed that males had significantly higher values of EPA and AA, while females had significantly higher levels of 18:4(n-3), 16:1(n-7) and 14:0 (Table 6).

\section{DISCUSSION}

\section{Echinoid gonadal indices}

As the gonad acts as a nutritive storage organ for echinoids (Walker et al. 2001), GSIs are used as the standard indicators of individual and population nutritive and reproductive status. In the current study, clear and significant variability of GSI with depth was found

Table 2. Psammechinus miliaris. Chi-squared analysis of distribution of sex, and maturity stage between depth, location and sex. Stage III: premature; Stage IV: mature

\begin{tabular}{|lccccc|}
\hline & Female & Male & Stage III & Stage IV \\
\hline Intertidal & 12 & 8 & 8 & 12 \\
Subtidal & 8 & 12 & 9 & 11 \\
& $\chi^{2}=$ & $1.600, \mathrm{p}=0.21$ & $\chi^{2}=0.102, \mathrm{p}=0.75$ \\
Rubha Garbh & 10 & 10 & 10 & 10 \\
South Shian & 10 & 10 & 7 & 13 \\
& $\chi^{2}=$ & $0.000, \mathrm{p}=1.00$ & $\chi^{2}=0.921, \mathrm{p}=0.34$ \\
Female & - & - & \multicolumn{2}{c}{15} & 5 \\
Male & - & - & & 2 & 18 \\
& & - & & $\chi^{2}=17.29, \mathrm{p}=0.000$ \\
\hline
\end{tabular}


Table 3. Psammechinus miliaris. Fatty acid composition of the gonad from the 2 locations at 2 depths. Replicates have been grouped; data are average \% of total FAME for each fatty acid and the 95\% confidence interval (CI) (n = 10). Total FAME is measured in $\mathrm{mg} \mathrm{g}^{-1}$ of urchin gonad. DMA: dimethylacetal; NMID: non-methylene interrupted dienes

\begin{tabular}{|c|c|c|c|c|c|c|c|c|}
\hline \multirow[t]{3}{*}{ Fatty acid } & \multicolumn{4}{|c|}{ Rubha Garbh } & \multicolumn{4}{|c|}{ South Shian } \\
\hline & \multicolumn{2}{|c|}{ Intertidal } & \multicolumn{2}{|c|}{ Subtidal } & \multicolumn{2}{|c|}{ Intertidal } & \multicolumn{2}{|c|}{ Subtidal } \\
\hline & Mean & $95 \% \mathrm{CI}$ & Mean & $95 \% \mathrm{CI}$ & Mean & $95 \% \mathrm{CI}$ & Mean & $95 \% \mathrm{CI}$ \\
\hline $14: 0$ & 3.84 & 0.72 & 3.74 & 0.85 & 2.79 & 0.76 & 3.45 & 0.78 \\
\hline a15:0 & 0.11 & 0.04 & 0.07 & 0.05 & 0.16 & 0.04 & 0.09 & 0.05 \\
\hline $15: 0$ & 0.65 & 0.09 & 0.62 & 0.16 & 0.64 & 0.12 & 0.54 & 0.07 \\
\hline $16: 0$ & 10.16 & 0.32 & 11.18 & 0.53 & 10.26 & 0.45 & 10.67 & 0.49 \\
\hline 16:1(n-7) & 3.08 & 0.76 & 2.70 & 1.12 & 1.66 & 0.43 & 2.92 & 1.03 \\
\hline $16: 2$ & 0.43 & 0.16 & 0.25 & 0.22 & 0.72 & 0.27 & 0.40 & 0.18 \\
\hline $17: 0$ & 0.22 & 0.05 & 0.36 & 0.46 & 0.53 & 0.09 & 0.18 & 0.05 \\
\hline $17: 1$ & 0.00 & 0.00 & 0.00 & 0.00 & 0.04 & 0.02 & 0.00 & 0.00 \\
\hline 16:0 DMA & 3.17 & 0.46 & 4.56 & 0.77 & 3.58 & 0.41 & 4.23 & 0.61 \\
\hline $16: 4$ & 0.26 & 0.14 & 0.13 & 0.15 & 0.12 & 0.06 & 0.26 & 0.12 \\
\hline $18: 0$ & 2.95 & 0.65 & 3.98 & 0.75 & 4.04 & 0.71 & 3.54 & 0.76 \\
\hline $18: 1(n-9)$ & 1.64 & 0.26 & 1.76 & 0.50 & 1.36 & 0.29 & 1.39 & 0.42 \\
\hline $18: 1(n-7)$ & 2.87 & 0.35 & 2.67 & 0.33 & 2.65 & 0.23 & 2.52 & 0.23 \\
\hline $18: 2(n-6)$ & 1.43 & 0.17 & 1.39 & 0.29 & 0.95 & 0.14 & 1.39 & 0.22 \\
\hline $18: 2(n-3)$ & 0.06 & 0.07 & 0.04 & 0.05 & 0.10 & 0.06 & 0.16 & 0.20 \\
\hline $18: 3(n-6)$ & 0.55 & 0.11 & 0.31 & 0.21 & 0.50 & 0.04 & 0.54 & 0.14 \\
\hline $18: 3(n-3)$ & 1.90 & 0.38 & 1.29 & 0.40 & 1.18 & 0.26 & 1.58 & 0.50 \\
\hline $18: 4(n-3)$ & 4.15 & 1.24 & 2.14 & 1.05 & 1.69 & 0.70 & 3.48 & 1.30 \\
\hline $20: 0$ & 0.49 & 0.07 & 0.52 & 0.17 & 0.49 & 0.03 & 0.58 & 0.08 \\
\hline 20:2 NMID & 5.79 & 0.94 & 7.06 & 1.49 & 6.32 & 0.23 & 5.98 & 0.71 \\
\hline 20:1(n-9) & 1.99 & 0.30 & 2.94 & 1.29 & 1.79 & 0.13 & 2.26 & 0.28 \\
\hline $20: 1(n-7)$ & 1.07 & 0.10 & 0.81 & 0.28 & 1.28 & 0.08 & 0.93 & 0.12 \\
\hline $20: 2(n-6)$ & 2.55 & 0.35 & 2.59 & 0.35 & 2.29 & 0.33 & 2.84 & 0.50 \\
\hline $21: 0$ & 0.30 & 0.04 & 0.10 & 0.01 & 0.19 & 0.03 & 0.23 & 0.08 \\
\hline $20: 4(n-6)$ & 11.56 & 1.44 & 14.20 & 2.48 & 11.07 & 1.19 & 12.50 & 2.07 \\
\hline $20: 3(n-3)$ & 2.29 & 0.19 & 1.62 & 0.26 & 1.69 & 0.24 & 1.93 & 0.27 \\
\hline $20: 4(n-3)$ & 0.86 & 0.20 & 0.36 & 0.22 & 0.57 & 0.16 & 0.62 & 0.22 \\
\hline $20: 5(n-3)$ & 16.34 & 1.44 & 17.37 & 1.81 & 15.06 & 1.94 & 18.39 & 1.48 \\
\hline $22: 1(n-11)$ & 0.12 & 0.06 & 0.07 & 0.07 & 0.18 & 0.06 & 0.08 & 0.05 \\
\hline $22: 1(n-9)$ & 4.22 & 0.31 & 3.81 & 0.36 & 3.14 & 0.25 & 3.79 & 0.35 \\
\hline $22: 2(n-6)$ & 0.07 & 0.04 & 0.15 & 0.25 & 0.12 & 0.01 & 0.10 & 0.04 \\
\hline $22: 5(n-3)$ & 0.92 & 0.22 & 0.67 & 0.28 & 1.61 & 0.24 & 1.02 & 0.20 \\
\hline $22: 6(n-3)$ & 2.16 & 0.78 & 2.27 & 0.55 & 7.52 & 1.59 & 2.03 & 0.39 \\
\hline Total PUFA & 42.33 & 2.11 & 42.71 & 3.03 & 41.41 & 3.12 & 44.15 & 2.72 \\
\hline Total SFA & 19.24 & 0.65 & 20.81 & 1.17 & 19.16 & 0.67 & 19.67 & 0.97 \\
\hline Total MUFA & 10.72 & 0.58 & 10.06 & 0.98 & 8.93 & 0.66 & 9.97 & 0.67 \\
\hline Total FAMEs & 7.84 & 3.26 & 6.43 & 1.94 & 42.26 & 18.05 & 36.64 & 9.61 \\
\hline
\end{tabular}

for Psammechinus miliaris on the west coast of Scotland. Individuals in the intertidal zone had a significantly higher GSI than those just a few meters deeper in the subtidal zone. Study locations were chosen such that the spatial distance between replicates was equiv-

Table 4. Psammechinus miliaris. ANOSIM of the fatty acid signature between replicate sites at each depth and location

\begin{tabular}{|lcrc|}
\hline & Depth & $\mathrm{R}$ & $\mathrm{p}$ \\
\hline Rubha Garbh & Intertidal & -0.104 & 83.3 \\
& Subtidal & 0.048 & 26.4 \\
South Shian & Intertidal & -0.024 & 42.9 \\
& Subtidal & -0.104 & 82.5 \\
\hline
\end{tabular}

alent to that between depths. Thus the differences between the GSI at the 2 depths were not attributable to patchiness at the scale of 10 s of meters. So our first hypothesis, that variation in the GSI is a result of depth and is independent of spatial variation, can be accepted.

Psammechinus miliaris in the intertidal zone are exposed for 1 to $2 \mathrm{~h}$ every tidal cycle during spring tides for periods of up to 3 to $5 \mathrm{~d}$. During these periods of exposure individuals were observed to be inactive and showed no evidence of feeding, although the period of inactivity was sometimes greater than the periods of exposure. We observed that even when immersed diurnally, the individuals in the intertidal were rarely located away from their cryptic refuges. 


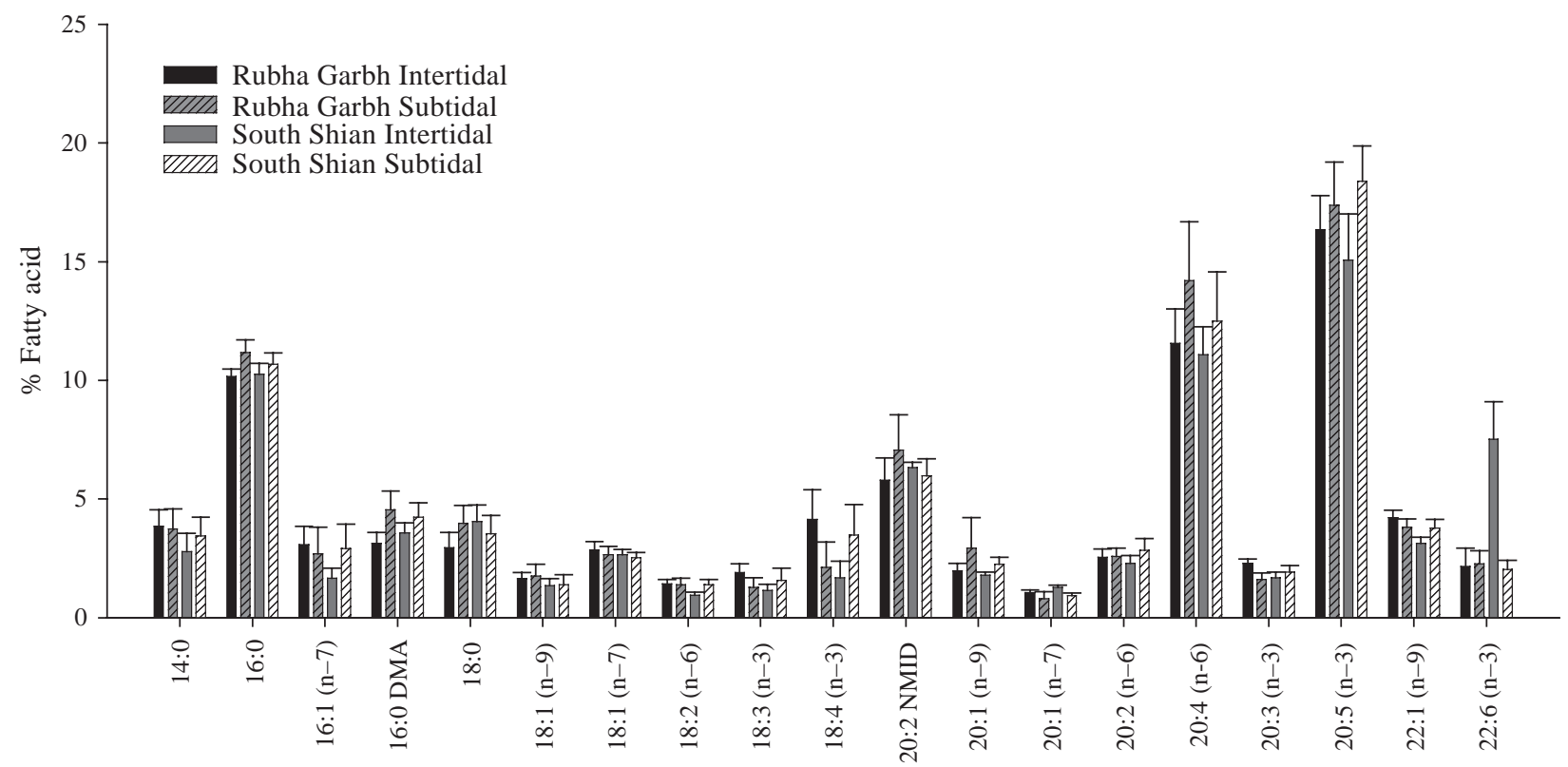

Fig. 5. Psammechinus miliaris. Mean $( \pm 95 \% \mathrm{CI}) \%$ of the primary fatty acids at each location and depth. DMA: dimethylacetal; NMID: non-methylene interrupted dienes

Given that individuals in the intertidal have less time to forage and are subject to higher levels of environmental stress, it remains uncertain as to why individuals at the limit of their depth distribution have higher GSI values than those in the subtidal.

\section{Fatty acid analysis}

The multivariate analysis of the fatty acid signature of the gonad of Psammechinus miliaris showed that clear distinctions existed between depth, location and

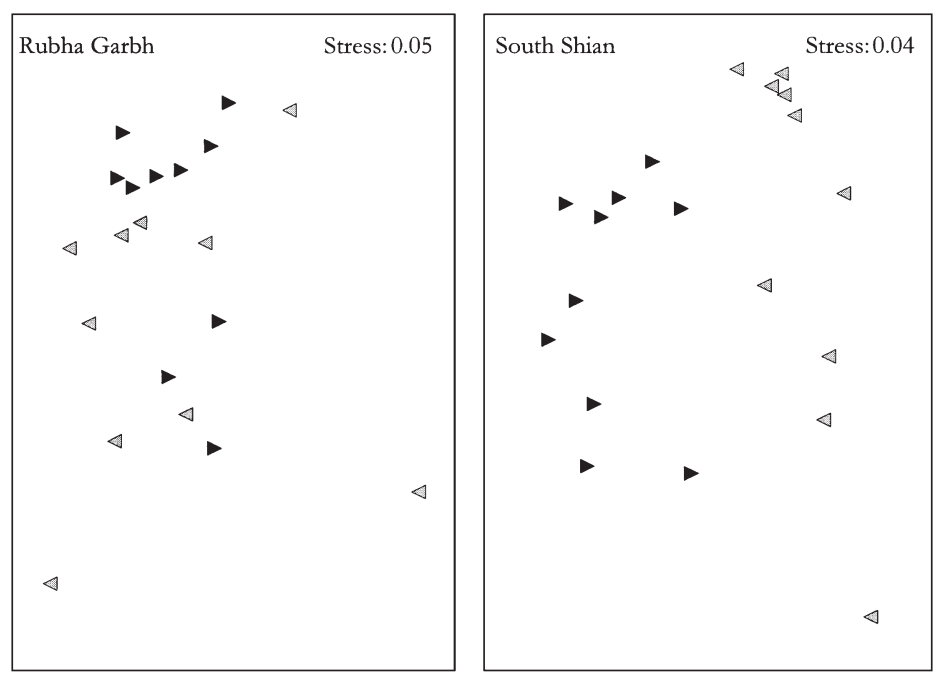

Fig. 6. Psammechinus miliaris. nMDS plots for fatty acid signature at the 2 study locations. $\downarrow$ = intertidal, $\triangleleft=$ subtidal sex. Differences in gonad biochemistry of echinoids between sexes have been previously reported. Fenaux (1977) and Magniez (1983) found different levels of protein, carbohydrate and lipid in male and female urchin gonads, and Borisovets et al. (2002) recorded different carotenoid levels for the sexes. This is the first time that sex differentiation in echinoids has been reported using fatty acid signatures. Although we found no sex variation in the GSI, the proportions of individual acids varied significantly. There is a degree of concordance with reported differences in other marine invertebrates. The ovaries of the limpet Patella depressa (Morais et al. 2003), the scallop Argopecten purpuratus (Caers et al. 1999) and a fish, Plecoglossus altivelis (Jeong et al. 2002), had higher proportions of $14: 0$ and 16:1(n-7), whereas testes had higher proportions of 20:4 (n-6) and 22:6(n-3). Such intersex differences were also observed in the gonads of $P$. miliaris. However, while the male limpet $P$. depressa had higher levels of 18:4(n-3), the opposite was found in P. miliaris gonads. This difference between the sexes is an important consideration when using fatty acid signatures to study the trophic ecology of natural populations that may, unlike $P$. miliaris, exhibit sex bias in spatial distribution (Guettaf et al. 2000). Seasonal patterns of change in fatty acid signature linked to the gametogenic cycle have been shown for a number of marine organisms (Pazos et al. 1997, Ojea et al. 2004, Rosa et al. 2004), and it 


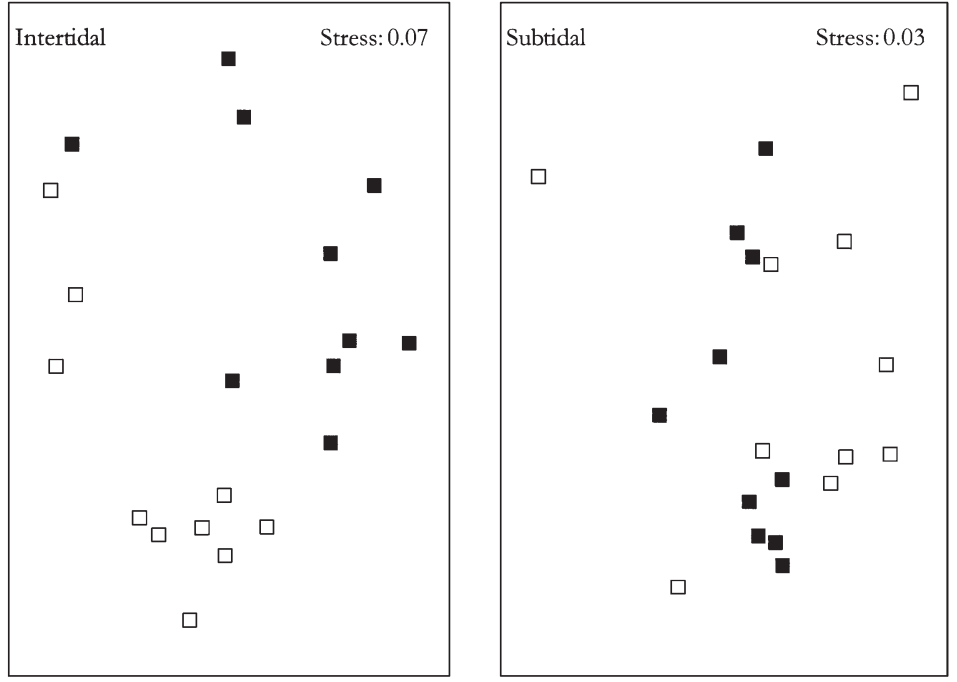

Fig. 7. Psammechinus miliaris. nMDS plots for fatty acid signature at the 2 depths. $\square=$ Rubha Garbh, $\mathbf{\square}=$ South Shian could have a larger effect on the fatty acid signature than sex or maturity stage. Fatty acid signatures of Harbour seals were found to vary at regional scales (100s of $\mathrm{km}$ ) and between individual haul-outs within 9 to $15 \mathrm{~km}$ (Iverson et al. 1997). Iverson (1997) found that this spatial variation was also mirrored in a number of prey species, and suggested differences in seal fatty acid signatures were a result not only of localized feeding patterns but also of the composition of their prey. Similarly, diet was linked with variation in the fatty acid profile of the gonad of the limpet Patella depressa, where variability in diet resulted from the availability of different algae communities due to wave and wind exposure (Morais et al. 2003). Differences in fatty acid signatures have also been linked to patterns of productivity in another very different mollusc, the squid Moroteuthis ingens (Phillips et al. 2003).

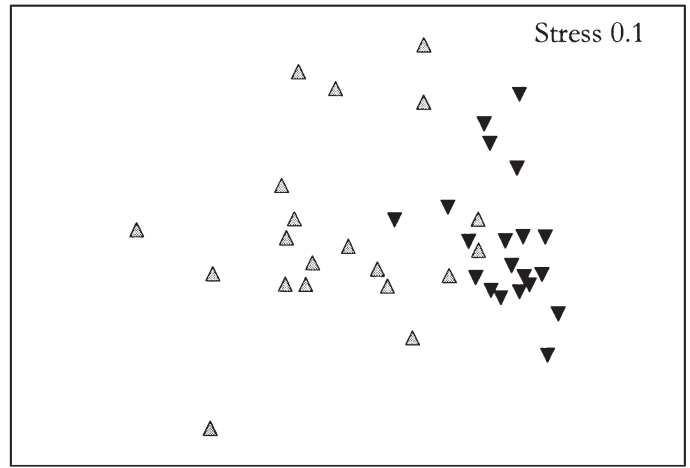

Fig. 8. Psammechinus miliaris. nMDS plots for fatty acid signature at all depths and locations. $\boldsymbol{\nabla}=$ female, $\Delta=$ male
We hypothesised that we would be able to differentiate between intertidal and subtidal populations on the basis of their fatty acid signature, and we have shown this to be supported. The patterns revealed by SIMPER showed that the subtidal populations have higher levels of the PUFAs EPA and AA. However, when using PUFAs as dietary indicators, it is important to recall that although the primary source of these compounds is synthesis by green algae, there are other sources that may confound a simple interpretation. The role that bacteria play in the synthesis of these compounds has been a subject of much interest (Nichols 2003). It has been shown that these bacteria are present in a range of marine invertebrates (Jostensen \& Landfald 1997), including sea urchins (Iwanami et al. would seem probable that such a pattern exists for $P$. miliaris. These findings highlight the need for further research to differentiate the effect of seasonal diet changes from gamete maturation, and to elucidate the functional significance of specific fatty acids and the role they play in the reproductive ecology of echinoids.

Our study showed that the fatty acid signature of Psammechinus miliaris gonads varies significantly at a scale of $10 \mathrm{~s}$ of kilometers, but not at the scale of $10 \mathrm{~s}$ of meters. Other studies have recorded significant intra-species heterogeneity in fatty acid signatures at a range of spatial scales. Cripps et al. (1999) concluded that regional variation in diet
Table 5. Psammechinus miliaris. Contribution of individual fatty acids to multivariate differences in fatty acid signatures between depths at each location as determined by SIMPER. For all fatty acids, samples were pooled within location except for 20:2 NMID at Rubha Garbh. NMID: non-methylene interrupted dienes

\begin{tabular}{|lrccrrr|}
\hline Fatty acid & \multicolumn{2}{c}{$\begin{array}{c}\text { Mean \% } \\
\text { Intertidal }\end{array}$} & $\begin{array}{c}\text { \% contri- } \\
\text { bution }\end{array}$ & $\begin{array}{c}\text { Cumu- } \\
\text { lative } \%\end{array}$ & $F$ & $p$ \\
\hline Rubha Garbh & & & & & & \\
20:4(n-6) & 11.56 & 14.19 & 13.43 & 13.43 & 3.25 & 0.08 \\
20:5(n-3) & 16.34 & 17.37 & 9.63 & 23.06 & 0.76 & 0.39 \\
18:4(n-3) & 4.15 & 2.14 & 8.94 & 32.00 & 5.87 & 0.02 \\
20:2 NMID & 5.79 & 7.06 & 7.87 & 39.87 & 1.22 & 0.38 \\
16:1(n-7) & 3.08 & 2.7 & 5.79 & 45.66 & 0.30 & 0.59 \\
South Shian & & & & & & \\
22:6(n-3) & 7.52 & 2.03 & 17.56 & 17.56 & 43.29 & $<0.01$ \\
20:5(n-3) & 15.06 & 18.39 & 13.67 & 31.23 & 0.76 & 0.39 \\
20:4(n-6) & 11.07 & 12.5 & 9.86 & 41.09 & 1.38 & 0.26 \\
18:4(n-3) & 1.69 & 3.48 & 7.88 & 48.98 & 5.64 & 0.03 \\
\hline
\end{tabular}


Table 6. Psammechinus miliaris. Contribution of individual fatty acids to multivariate differences in fatty acid signatures between sex as determined by SIMPER. $F$ and associated $p$ were obtained from 1-way ANOVA

\begin{tabular}{|c|c|c|c|c|c|c|c|c|}
\hline \multirow[b]{2}{*}{ Fatty acid } & \multicolumn{2}{|c|}{ Females } & \multicolumn{2}{|c|}{ Males } & \multirow{2}{*}{$\begin{array}{c}\% \\
\text { contribution }\end{array}$} & \multirow{2}{*}{$\begin{array}{c}\text { Cumulative } \\
\%\end{array}$} & \multirow{2}{*}{$F$} & \multirow{2}{*}{$\mathrm{p}$} \\
\hline & Mean \% & $95 \% \mathrm{CI}$ & Mean \% & $95 \%$ CI & & & & \\
\hline 20:4(n-6) & 10.31 & 4.52 & 14.36 & 6.29 & 12.55 & 12.55 & 31.79 & $<0.001$ \\
\hline 20:5(n-3) & 15.12 & 6.63 & 18.46 & 8.09 & 11.65 & 24.2 & 19.80 & 0.001 \\
\hline 18:4(n-3) & 4.31 & 1.89 & 1.41 & 0.62 & 8.86 & 33.06 & 46.92 & $<0.001$ \\
\hline $22: 6(n-3)$ & 2.65 & 1.16 & 4.34 & 1.9 & 8.75 & 41.81 & 4.02 & 0.052 \\
\hline $16: 1(n-7)$ & 3.5 & 1.53 & 1.68 & 0.74 & 6.06 & 47.87 & 24.63 & $<0.001$ \\
\hline $14: 0$ & 4.39 & 1.93 & 2.52 & 1.1 & 5.94 & 53.81 & 48.37 & $<0.001$ \\
\hline
\end{tabular}

1995). In addition, Psammechinus miliaris is capable of synthesising some PUFAs de novo (Bell et al. 2001).

The subtidal sites in this study were dominated by the macroalgae Laminaria saccharina. The fatty acid profile of L. saccharina is rich in 18:1(n-9), 18:4(n-3), 20:4(n-6) and 20:5(n-3) (Fleurence et al. 1994, Mai et al. 1996). The subtidal populations of urchins at both locations had higher values of 18:1(n-9), 20:4(n-6) and 20:5(n-3), indicating that L. saccharina may be an important component of the subtidal diet. Green algae are rich in 16:0, 16:4, 18:3(n-3), and 18:4(n-3) (Johns et al. 1979, Khotimchenko et al. 2002). The intertidal urchins at RG and the subtidal urchins at SS had significantly higher levels of 18:4(n-3) than the other depth at those sites. They also exhibited higher levels of 16:4 and 18:4(n-3), indicative of a diet containing green algae. The intertidal population at SS had significantly higher levels of 22:6(n-3). This fatty acid is found at low concentrations in marine macroalgae (Jamieson \& Reid 1972) and at high concentrations in dinoflagellate microalgae (Viso \& Marty 1993). It has been associated with filter (Cook et al. 2000) or suspension feeding invertebrates (Howell et al. 2003), and can also be characteristic of carnivores (Kharlamenko et al. 1995). This would indicate a complicated site- and depthdependent pattern of trophic interactions for Psammechinus miliaris. Urchins at the intertidal at SS exhibited higher levels of carnivory compared to subtidal individuals, which had a diet consisting predominantly of green and brown algae. The diet of intertidal urchins at RG was dominated by green algae, and in the subtidal primarily by L. saccharina.

Urchins fed omnivorous or carnivorous diets have higher levels of growth, both somatic and gonadal, than those fed purely algal diets (Cook et al. 1998). Kelp is of limited nutritional value to sea urchins (Otero-Villanueva et al. 2004) and leads to poor growth (Vadas et al. 2000). These findings support the hypothesis by Kelly (2000) that differences in gonadal indices between intertidal and subtidal populations were a result of increased food quality and/or quantity available in the intertidal. Further investigation is required to better understand the relationship between gonad biomass and fecundity, and the role that nutrition plays in echinoid reproduction.

We suggest that urchins in our study populations were food limited and ate animal material where available to increase somatic and reproductive production. Algae became the default diet when grazing pressure or benthic productivity limited the availability of animal prey. There was an ecological 'pay off' for individuals living at the limit of their distribution: they were subject to harsher environmental conditions and reduced foraging times, but they had access to food of a sufficiently higher quality to maintain and even increase their GSI compared to those in the subtidal.

Acknowledgements. We thank Dr. E. Cook for her help and H. Muir for technical support for fatty acid analyses and her unstinting patience. We also thank the Leonardo da Vinci scholarship for facilitating the visit of A.I.C. to the Scottish Association for Marine Science. This research was funded under NERC PhD studentship NER/S/A/2002/1055.

\section{LITERATURE CITED}

Bell MV, Dick JR, Kelly MS (2001) Biosynthesis of eicosapentaenoic acid in the sea urchin Psammechinus miliaris. Lipids 36:79-82

Black KD, Hughes DJ, Provost PG, Pereira PMF (2000) Broad scale survey and mapping of seabed biota in Loch Creran, Argyll. Report no. F98AA408, Scottish Natural Heritage, Edinburgh

Borisovets EE, Zadorozhny PA, Kalinina MV, Lepskaya NV, Yakush EV (2002) Changes of major carotenoids in gonads of sea urchins (Strongylocentrotus intermedius and $S$. nudus) at maturation. Comp Biochem Physiol B 132: 779-790

Boyd CM, Smith SL, Cowles TJ (1980) Grazing patterns of copepods in the upwelling system off Peru. Limnol Oceanogr 25:583-596

Briscoe CS, Sebens KP (1988) Omnivory in Strongylocentrotus droebachiensis (Muller) (Echinodermata, Echinoidea): predation on subtidal mussels. J Exp Mar Biol Ecol 115: $1-24$

Caers M, Coutteau P, Cure K, Morales V, Gajardo G, Sorgeloos P (1999) The Chilean scallop Argopecten purpuratus (Lamarck, 1819). I. Fatty acid composition and 
lipid content of six organs. Comp Biochem Physiol B 123: 89-96

Cook EJ, Kelly MS, McKenzie JD (1998) Somatic and gonadal growth of the sea urchin Psammechinus miliaris (Gmelin) fed artificial salmon feed compared with a macroalgal diet. J Shellfish Res 17:1549-1555

Cook EJ, Bell MV, Black KD, Kelly MS (2000) Fatty acid compositions of gonadal material and diets of the sea urchin, Psammechinus miliaris: trophic and nutritional implications. J Exp Mar Biol Ecol 255:261-274

Cripps GC, Watkins JL, Hill HJ, Atkinson A (1999) Fatty acid content of Antarctic krill Euphausia superba at South Georgia related to regional populations and variations in diet. Mar Ecol Prog Ser 181:177-188

Dalsgaard J, St John M, Kattner G, Muller-Navarra D, Hagen W (2003) Fatty acid trophic markers in the pelagic marine environment. In: Southward AJ, Taylor PA, Young CM, Fuiman LA (eds) Advances in marine biology, Vol 46. Academic Press, London, p 225-340

Fenaux L, Malara G, Cellario C, Charra R, Palazzoli I (1977) Evolution of biochemical components of principal compartments of sea urchin body, Arbacia-Lixula (L), during sexual cycle and effect of short-term food-deprivation during sexual-maturation. J Exp Mar Biol Ecol 28:17-30

Fernandez C, Boudouresque CF (2000) Nutrition of the sea urchin Paracentrotus lividus (Echinodermata : Echinoidea) fed different artificial food. Mar Ecol Prog Ser 204:131-141

Fleurence J, Gutbier G, Mabeau S, Leray C (1994) FattyAcids from 11 marine macroalgae of the French Brittany coast. J Appl Phycol 6:527-532

Floreto EAT, Teshima S, Ishikawa M (1996) The effects of seaweed diets on the growth, lipid and fatty acids of juveniles of the white sea urchin Tripneustes gratilla. Fish Sci 62: 589-593

Forster GR (1959) The ecology of Echinus esculentus L. Quantitative distribution and rate of feeding. J Mar Biol Assoc UK 38:361-367

Fry B, Sherr EB (1984) Delta-C-13 measurements as indicators of carbon flow in marine and fresh-water ecosystems. Contrib Mar Sci 27:13-47

Grahl-Nielsen O, Andersen M, Derocher AE, Lydersen C, Wiig O, Kovacs KM (2003) Fatty acid composition of the adipose tissue of polar bears and of their prey: ringed seals, bearded seals and harp seals. Mar Ecol Prog Ser 265:275-282

Guettaf M, San Martin GA, Francour P (2000) Interpopulation variability of the reproductive cycle of Paracentrotus lividus (Echinodermata: Echinoidea) in the south-western Mediterranean. J Mar Biol Assoc UK 80:899-907

Himmelman JH, Steele DH (1971) Foods and predators of the green sea urchin Strongylocentrotus droebachiensis in Newfoundland waters. Mar Biol 9:315-322

Howell KL, Pond DW, Billett DSM, Tyler PA (2003) Feeding ecology of deep-sea seastars (Echinodermata: Asteroidea): a fatty-acid biomarker approach. Mar Ecol Prog Ser 255: 193-206

Iverson SJ, Frost KJ, Lowry LF (1997) Fatty acid signatures reveal fine scale structure of foraging distribution of harbor seals and their prey in Prince William Sound, Alaska. Mar Ecol Prog Ser 151:255-271

Iwanami H, Yamaguchi T, Takeuchi M (1995) Fatty acid metabolism in bacteria that produce eicosapentaenoic acid isolated from sea urchin Strongylocentrotus nudus. Nippon Suisan Gakkaishi 61:205-210

Jamieson GR, Reid EH (1972) Component fatty acids of some marine algal lipids. Phytochemistry 11:1423-1432

Jeong BY, Jeong WG, Moon SK, Ohshima T (2002) Preferen- tial accumulation of fatty acids in the testis and ovary of cultured and wild sweet smelt Plecoglossus altivelis. Comp Biochem Physiol B 131:251-259

Johns RB, Nichols PD, Perry GJ (1979) Fatty acid composition of 10 marine algae from Australian waters. Phytochemistry 18:799-802

Jostensen JP, Landfald B (1997) High prevalence of polyunsaturated fatty acid producing bacteria in arctic invertebrates. FEMS Microbiol Lett 151:95-101

Kelly MS (2000) The reproductive cycle of the sea urchin Psammechinus miliaris (Echinodermata: Echinoidea) in a Scottish sea loch. J Mar Biol Assoc UK 80:909-919

Kelly MS (2001) Environmental parameters controlling gametogenesis in the echinoid Psammechinus miliaris. J Exp Mar Biol Ecol 266:67-80

Kelly MS, Cook EJ (2001) The ecology of Psammechinus miliaris. In: Lawrence JM (ed) Edible sea urchins: biology and ecology. Elsevier Science, Amsterdam, p 217-224

Kharlamenko VI, Zhukova NV, Khotimchenko SV, Svetashev VI, Kamenev GM (1995) Fatty acids as markers of food sources in a shallow-water hydrothermal ecosystem (Kraternaya Bight, Yankich Island, Kurile Islands). Mar Ecol Prog Ser 120:231-241

Khotimchenko SV, Vaskovsky VE, Titlyanova TV (2002) Fatty acids of marine algae from the Pacific coast of north California. Bot Mar 45:17-22

Kleppel GS, Pieper RE (1984) Phytoplankton pigments in the gut contents of planktonic copepods from coastal waters off southern California. Mar Biol 78:193-198

Laureillard J, Mejanelle L, Sibuet M (2004) Use of lipids to study the trophic ecology of deep-sea xenophyophores. Mar Ecol Prog Ser 270:129-140

Lawerence JM (1975) On the relationships between marine plants and sea urchins. Oceanogr Mar Biol Annu Rev 13: 213-286

Magniez P (1983) Reproductive cycle of the brooding echinoid Abatus cordatus (Echinodermata) in Kerguelen (Antarctic Ocean): changes in the organ indexes, biochemical composition and caloric content of the gonads. Mar Biol 74:55-64

Mai KS, Mercer JP, Donlon J (1996) Comparative studies on the nutrition of two species of abalone, Haliotis tuberculata L. and Haliotis discus. The role of polyunsaturated fatty acids of macroalgae in abalone nutrition. Aquaculture 139:77-89

Morais S, Boaventura D, Narciso L, Re P, Hawkins SJ (2003) Gonad development and fatty acid composition of Patella depressa Pennant (Gastropoda: Prosobranchia) populations with different patterns of spatial distribution, in exposed and sheltered sites. J Exp Mar Biol Ecol 294: $61-80$

Nichols DS (2003) Prokaryotes and the input of polyunsaturated fatty acids to the marine food web. FEMS Microbiol Lett 219:1-7

Ojea J, Pazos AJ, Martinez D, Novoa S, Sanchez JL, Abad M (2004) Seasonal variation in weight and biochemical composition of the tissues of Ruditapes decussatus in relation to the gametogenic cycle. Aquaculture 238:451-468

Otero-Villanueva MDM, Kelly MS, Burnell G (2004) How diet influences energy partitioning in the regular echinoid Psammechinus miliaris; constructing an energy budget. J Exp Mar Biol Ecol 304:159-181

Pazos AJ, Roman G, Acosta CP, Sanchez JL, Abad M (1997) Lipid classes and fatty acid composition in the female gonad of Pecten maximus in relation to reproductive cycle and environmental variables. Comp Biochem Physiol B $117: 393-402$ 
Pearce CM, Daggett TL, Robinson SMC (2004) Effect of urchin size and diet on gonad yield and quality in the green sea urchin (Strongylocentrotus droebachiensis). Aquaculture 233:337-367

Phillips KL, Jackson GD, Nichols PD (2003) Temporal variations in the diet of the squid Moroteuthis ingens at Macquarie Island: stomach contents and fatty acid analyses. Mar Ecol Prog Ser 256:135-149

Pond DW, Dixon DR, Bell MV, Fallick AE, Sargent JR (1997) Occurrence of $16: 2(n-4)$ and 18:2(n-4) fatty acids in the lipids of the hydrothermal vent shrimps Rimicaris exoculata and Alvinocaris markensis: nutritional and trophic implications. Mar Ecol Prog Ser 156:167-174

Rosa R, Costa PR, Nunes ML (2004) Effect of sexual maturation on the tissue biochemical composition of Octopus vulgaris and O. defflippi (Mollusca: Cephalopoda). Mar Biol 145:563-574

Sargent JR, Falkpetersen S (1981) Ecological investigations on the zooplankton community in balsfjorden, northern Norway: lipids and fatty acids in Meganyctiphanes

Editorial responsibility: John Lawrence (Contributing Editor), Tampa, Florida, USA norvegica, Thysanoessa raschi and Thysanoessa inermis during mid-winter. Mar Biol 62:131-137

Underwood AJ (1997) Experiments in ecology: their logical design and interpretation using analysis of variance. Cambridge University Press, Cambridge

Vadas RL, Beal B, Dowling T, Fegley JC (2000) Experimental field tests of natural algal diets on gonad index and quality in the green sea urchin, Strongylocentrotus droebachiensis: a case for rapid summer production in postspawned animals. Aquaculture 182:115-135

Viso AC, Marty JC (1993) Fatty acids from 28 marine microalgae. Phytochemistry 34:1521-1533

Walker CW, Unuma T, McGinn NA, Harrington LM, Lesser MP (2001) Reproduction of sea urchins. In: Lawrence JM (ed) Edible sea urchins: biology and ecology. Elsevier Science, Amsterdam, p 5-26

Warwick RM, Clarke KR, Gee JM (1990) The effect of disturbance by soldier crabs Mictyris platycheles H. Milne Edwards, on meiobenthic community structure. J Exp Mar Biol Ecol 135:19-33

Submitted: March 15, 2005; Accepted: July 14, 2005 Proofs received from author(s): November 8, 2005 